\title{
Gangguan Fungsi Jantung pada Thalassemia Mayor
}

\author{
Fajar Subroto, Najib Advani
}

\begin{abstract}
Penimbunan besi akibat tranfusi darah berulang pada thalassemia dapat mengakibatkan terjadinya komplikasi pada jantung. Gangguan kontraktilitas otot jantung dan irama jantung menunjukkan banyaknya besi yang tertimbun di serabut otot. Toksisitas besi terhadap jantung akan menyebabkan reaksi katalisis dalam sel miokardium dan jaringan parenkim sehingga membentuk hidroksi radikal bebas yang akan mengakibatkan kerusakan sel. Kelainan fungsi jantung pada thalassemia, mayor terutama berhubungan dengan gangguan fungsi ventrikel, septum intraventrikular serta diikuti dilatasi atrium kiri dan ventrikel kanan. Pemeriksaan elektrokardiografi (EKG) dapat mencerminkan adanya gangguan fungsi hantaran jantung yaitu antara lain adanya perlambatan konduksi atrioventrikular. Pemeriksaan ekokardiografi jantung dapat lebih tepat menilai kelainan anatomis dan penurunan fungsi kontraksi jantung antara lain dengan pengukuran fraksi ejeksi ventrikel.
\end{abstract}

Kata kunci: thalassemia, besi, EKG, ekokardiografi

$\tau$

halassemia merupakan penyakit yang menimbulkan masalah kesehatan global, terutama di negara dengan frekuensi thalassemia tinggi, yaitu daerah Mediteranean di daerah laut tengah hingga daerah sekitar khatulistiwa. ${ }^{1}$

Anemia berat dan progresif pada thalassemia mayor mengakibatkan kardiomegali sebagai akibat sirkulasi yang hiperdinamis, bahkan dapat mengakibatkan kematian di usia dini. Perubahan anatomis yang tampak jelas termasuk dilatasi atrium dan ventrikel serta menipisnya dinding jantung mengakibatkan jantung dapat membesar hingga 2-3 kali ukuran normal. Ukuran jantung dapat normal kembali apabila diberikan transfusi secara optimal. ${ }^{1}$ Tetapi transfusi darah berulang akan menyebabkan terjadinya penimbunan besi (iron overload) di berbagai organ antara lain jantung sehingga

Dr. Fajar Subroto: PPDS IKA-FKUI.

\section{Alamat korespondensi:}

Dr. Najib Advani, Sp.A(K), MM Paed.

Staf Subbagian Kardiologi. Bagian Ilmu Kesehatan Anak FKUI-RSCM. Jl. Salemba no. 6, Jakarta 10430.

Telepon: 021-3155742, Fax.: 021-3913982. pengobatan dengan transfusi berulang pada pasien thalassemia mayor hanya dapat mengubah saat kematian, dari kematian dini akibat anemia di masa kanak-kanak menjadi kematian akibat timbunan besi di masa remaja dan dewasa muda. ${ }^{2-5}$

Di dalam naskah ini akan dibahas mengenai gangguan fungsi jantung pada thalassemia mayor.

\section{Penyebab gangguan fungsi jantung}

Terjadinya komplikasi jantung akibat timbunan besi ini sering ditemukan setelah melewati dekade pertama kehidupan dan menjadi penyebab utama kematian. Secara mikroskopis terlihat bahwa timbunan besi mulamula terjadi di otot ventrikel dan selanjutnya terjadi di jaringan konduksi. Terdapatnya gangguan kontraktilitas otot jantung dan irama jantung menunjukkan jumlah besi yang tertimbun di serabut otot dan jumlah serabut otot yang terkena. ${ }^{4}$ Terlihatnya gejala gangguan fungsi jantung menunjukkan prognosis yang buruk, pada umumnya pasien thalassemia akan meninggal karena gagal jantung kongesti dengan gangguan fungsi ventrikel kiri dan aritmia dalam waktu kurang dari satu tahun setelah timbulnya gejala gangguan jantung. ${ }^{3-5}$ 
Toksisitas besi terhadap jantung terjadi akibat penimbunan besi dalam sel miokardium dan jaringan parenkim sehingga akan menyebabkan reaksi katalisis yang membentuk hidroksi radikal bebas sehingga terjadi peroksidasi lipid di mitokondria, lisosom dan membran sel yang akan mengakibatkan kerusakan sel, kematian jaringan serta akhirnya kerusakan organ..$^{6-8}$

Beratnya kelainan fungsi jantung bergantung dari jumlah timbunan besi per serabut otot serta jumlah serabut otot yang terkena. ${ }^{4}$ Jumlah transfusi yang telah melebihi 100 unit berhubungan dengan jumlah timbunan besi yang terlihat secara jelas, maupun gejala gangguan jantung kongesti sepanjang hidupnya. Gangguan dapat berupa kelainan irama jantung maupun kontraktilitas otot jantung. Pasien thalassemia, mayor dapat meninggal akibat kelainan jantung yang berhubungan dengan gagal jantung biventrikular atau kematian mendadak karena aritmia jantung. ${ }^{2,3}$ Kematian akibat intractable aritmia dan/atau kardiomiopati kongestif umumnya terjadi pada umur 18 atau 20 tahun, pasien jarang bertahan hidup sampai umur 25 tahun. ${ }^{9}$

Kelainan fungsi jantung pada thalassemia, mayor terutama berhubungan dengan gangguan fungsi ventrikel, yaitu terjadi kelainan diastolik ventrikel kiri restriktif yang disertai peningkatan ketebalan dinding posterior ventrikel kiri dan septum interventrikular, diikuti dilatasi atrium kiri dan ventrikel kanan. ${ }^{9-11}$ Selain itu dapat terjadi juga regurgitasi katup trikuspid dan gangguan pengisian diastolik ventrikel kanan sebagai akibat terjadinya hipertensi pulmonal karena kelebihan besi dan timbunan besi di paru maupun ventrikel. ${ }^{10}$ Dari penelitian terhadap penderita thalassemia, mayor dengan pemberian deferoxamine di tiga rumah sakit anak Toronto, Boston, dan Philadelphia di dapatkan prevalensi gangguan jantung sebesar $37 \%{ }^{11}$

Penelitian yang dilakukan oleh Spirito dkk, ${ }^{9}$ untuk menilai pola pengisian ventrikel kiri menggunakan ekokardiografi Doppler pada 32 pasien thalassemia mayor yang tidak menderita gejala gagal jantung serta mempunyai fungsi sistolik ventrikel kiri yang normal, menunjukkan adanya restriksi pengisian ventrikel kiri, baik yang mendapat terapi kelasi maupun yang tidak. Dari penelitian ini juga didapatkan bahwa terapi kelasi besi dengan deferoxamine tidak dapat rnemproteksi secara penuh terhadap timbulnya kerusakan jantung akibat toksisitas besi. ${ }^{9}$ Sedangkan penelitian Ehlers dkk, ${ }^{12}$ menunjukkan bahwa tatalaksana deferoxamine dengan dosis yang benar dapat menghambat timbulnya komplikasi jantung dan meningkatkan umur rata-rata pasien thalassemia.

\section{Pemeriksaan gangguan hantaran jantung dengan elektrokardiografi}

Jantung mempunyai otot yang bersifat unik karena mempunyai otomatisasi kontraksi yang ritmik. Impuls listrik memacu kontraksi, yang berjalan melalui sistem konduksi khusus, yang menimbulkan arus listrik lemah kemudian menyebar ke seluruh tubuh. Adanya berbagai kelainan pada jantung seperti gangguan miokard, hipertrofi, efusi perikardium, gangguan konduksi, gangguan metabolik atau elektrolit, maupun irama jantung dapat tercermin pada elektrokardiografi. ${ }^{13}$ Kelainan EKG yang paling sering ditemukan pada thalassemia, mayor adalah hipertrofi ventrikel kiri, disritmia dan perlambatan konduksi atrioventrikular (blok jantung derajat I dan II)

\section{Pemeriksaan gangguan fungsi jantung dengan ekokardiografi}

Ekokardiografi saat ini sudah merupakan bagian integral dalam evaluasi sistem kardiovaskular. Alat ini dapat digunakan untuk menilai kelainan anatomis dan penurunan fungsi jantung pada thalassemia, mayor. Dikenal beberapa pemeriksaan ekokardiografi, yaitu ekokardiografi $2 \mathrm{dn}$ *ensi, $M$-mode dan $M$-mode dengan Doppler. Ekokardiografi $M$-mode merupakan tayangan refleksi gelombang ultrasonografi dari pelbagai kedalaman pada sumbu vertikal dengan waktu pada sumbu horizontal, sehingga ideal untuk melakukan pengukuran berbagai dimensi ruang jantung dan pembuluh darah, karena dapat dilakukan tepat pada saat siklus jantung yang dikehendaki (dengan EKG sebagai petanda), dan pada tempat yang dikehendaki (dalam kombinasi dengan ekokardiografi 2-dimensi). Sedangkan ekokardiografi 2-dimensi merupakan pemeriksaan ekokardiografi dari berbagai sudut pandang, yang dianggap pandangan baku adalah pandangan subkostal parasternal, apikal, dan suprasternal.

Fungsi jantung pada penelitian ini diukur melalui beberapa parameter untuk menentukan adanya gangguan fungsi sistolik ventrikel kiri, serta fungsi diastolik ventrikel kiri dan kanan, diantaranya adalah: dimensi sistolik akhir, dimensi diastolik akhir, prosentase pemendekan diameter ventrikel selama sistolik, fraksi ejeksi, ketebalan dinding posterior dan septum ventrikel, kecepatan maksimal pengisian 
Sari Pediatri, Vol. 5, No. 1, Juni 2003

ke-3. Philadelphia: Mosby, 1996. h. 67-82.

15. Snider AR, Sewer EA, Rutter SB. Echocardiography in Pediatric Heart Diseases. Edisi ke-2. St Louis: Mosby, 1997. h. 195-226

16. Lau KC, Li AMC, Hui PW, Yeung CY. Left ventricular function in, thalasaemia major. Arch Dis Child 1989; 64:1046-51.

17. Koren A, Garty I, Antonelli D, Katzuni E. Right ventricular cardiac dysfunction in ,-thalassemia major. Am J Dis Child 1987; 141:93-6. 
ventrikel pada saat awal diastolik (E), kecepatan maksimal pengisian ventrikel pada saat kontraksi atrium (A), dan rasio kecepatan maksimal pengisian awal dan akhir (E/A).

Prosentase pemendekan diameter ventrikel selama sistolik atau fraksi pemendekan merupakan suatu indikator fungsi ventrikel kiri yang sederhana dan banyak digunakan. ${ }^{12}$ Fraksi pemendekan ini dihitung dari perubahan prosentase diameter ventrikel kiri yang terjadi saat sistolik dengan mengukur diameter sistolik akhir dan diameter diastolik akhir menggunakan $M$ mode ekokardiografi. Nilai normal fraksi pemendekan adalah $28-44 \%$ dengan rata-rata $36 \% .{ }^{14}$ Pengukuran ini tidak tergantung umur dan laju jantung tetapi tergantung dan preload dan afterload ventrikel. Pada anak dengan kardiomiopati, kongestif akan terjadi penurunan fraksi pemendekan ini hingga $16 \pm 7 \%$ dari anak normal. ${ }^{15}$

Fraksi ejeksi yang diukur dengan ekokardiografi Doppler merupakan teknik analisis volume sebagai indikator fungsi pompa ventrikel, dengan nilai berkisar antara 64\%-83\% dengan rerata $74 \%$. Koren $\mathrm{dkk},{ }^{17}$ dalam penelitiannya mengenai disfungsi ventrikel kanan pada thalassemia, mayor, menggunakan nilai normal untuk fraksi ejeksi ventrikel kanan $40 \%$ atau lebih dan fraksi ejeksi ventrikel kiri 50\% atau lebih. Pemeriksaan ekokardiografi $M$-mode yang dilakukan oleh Lau dkk, ${ }^{16}$ untuk membandingkan kelompok anak normal dengan pasien thalassemia, mayor yang mendapat transfusi berulang dan tidak sedang mengalami gagal jantung menunjukkan terjadinya penurunan nilai fraksi pemendekan dan fraksi ejeksi ventrikel kiri. Pasien yang mengalami kelainan ini kemudian meninggal dalam kurun waktu 12 bulan sesudahnya karena dekompensasi jantung. ${ }^{12}$ Dari penelitian ini juga didapatkan bahwa dilatasi ventrikel kiri terlihat jelas pada pasien thalassemia , mayor. Dikemukakan pula bahwa analisis komputer dengan ekokardiografi $M$-mode merupakan metode yang layak untuk menilai fungsi jantung. Lau dkk, ${ }^{16}$ menyatakan juga bahwa fraksi pemendekan dan fraksi ejeksi merupakan indikator yang baik untuk menilai fungsi jantung.

Pada umumnya akan terjadi penurunan yang signifikan dari fraksi ejeksi pasien thalassemia dibandingkan anak normal. ${ }^{14}$ Pemeriksaan ekokardiografi dapat pula menilai adanya peningkatan ketebalan dinding posterior ventrikel dan ketebalan septum interventrikular. ${ }^{3,8}$ Melalui pemeriksaan ekokardiografi Doppler dapat pula diukur kecepatan maksimal pengisian ventrikel pada awal diastolik (E) dan saat kontraksi atrium (A), rasio kecepatan maksimal pengisian awal, dan akhir diastolik (E/A). Pada thalassemia akan terlihat gambaran restriktif, yaitu terlihat peningkatan nilai E, penurunan nilai $A$, serta peningkatan rasio E/A, baik di katup mitral maupun trikuspidal; hal ini mengindikasikan penurunan kemampuan diastolik ventnikel kiri dan kanan. ${ }^{9}$

\section{Daftar Pustaka}

1. Weatherall DJ, Clegg JB. The, thalassaemias. Dalam: Weatherall DJ, Clegg JB, penyunting. The Thalassaemia Syndromes edisi ke-3. London: Blackwell scientific publications, 1981. h. 148-319.

2. Leon MB, Borer JS, Bacharach SL. Detection of early cardiac dysfunction in patients with severe beta-thalassemia and chronic iron overload. N Engl J Med 1979; 22:1143-8.

3. Kremastinos DT, Tsiapras DP, Tsetsos GA. Left ventricular diastolic doppler characteristics in ,-thalassemia major. Circulation 1993; 88:1127-35.

4. McDonagh KT, Nenhuis AW. The thalassemias. Dalam: Nathan DG, Oski FA, penyunting. Hematology of infancy and childhood; edisi ke-4. Philadelphia: WB Saunders, 1993. h. 783-857.

5. Oesman IN. Gagal jantung. Dalam: Sastroasmoro S, Madiyono B, penyunting. Buku Ajar Kardiologi Anak. IDAI. Jakarta: Binarupa Aksara, 1994. h. 425-32.

6. Wijaya A. Radikal bebas dan parameter status antioksidan. Forum Diagnosticum, 1996; 1:1-6.

7. McCord JM. Iron, free radicals, and oxidative injury. Semin Hem 1998; 35:5-12.

8. Olivieri NF, Brittenham GM. Iron-chelating therapy and the treatment of thalassemia. Blood 1997; 89:739-54.

9. Spirito P, Lupi C, Melevendi C, Vecchio C. Restrictive diastolic abnormalities identified by Doppler echocardigraphy in patients with thalassemia major. Circulation 1990; 82:88-94.

10. Grisaru D, Rachmilewitz EA, Mosseri M. Cardiopulmonary assessment in beta-thalassemia major. Chest 1990; 98:1138-42.

11. Olivieri NF, Nathan DG, Mac Millan JH, et al. Survival in medically treated patients with homozygous,-thalassemia. N Eng J Med 1994; 331:574-8.

12. Ehlers KH, Giardina PJ, Lesser ML, et al. Prolonged survival in patients with beta-thalassemia major treated with deferoxamine. J Pediatr 1991; 118:540-5.

13. Sastroasmoro S. Ekokardiografi. Dalam: Sastroasmoro S. Madiyono B, penyunting. Buku ajar kardiologi anak. Jakarta: Ikatan Dokter Anak Indonesia. Jakarta, 1994. h. 103-26.

14. Park MK. Noninvasiv... Techniques. Dalam: Park MK, penyunting. Pediatric cardiology for practitioner; edisi 